\title{
Synthesis and characterization of new soluble polyamides from Acenaphtohydrazinomercaptotriazole diamine
}

\author{
Hossein Mighani1* and Najmeh Kia² \\ ${ }^{1}$ Department of Chemistry, Golestan University, Gorgan, Iran \\ 2Department of Chemistry, Qaemshahr Branch, Islamic Azad University, Qaemshahr, Mazandaran, Iran \\ *h.mighani@gu.ac.ir
}

\begin{abstract}
A diamine Acenaphtohydrazinomercaptotriazole (AHTD) was synthesized in one step from acenaphthoqinone and 4-amino-3-hydrazino-5-mercapto-1,2,4-triazole. The diamin was characterized by FTIR, ${ }^{1} \mathrm{HNMR},{ }^{13} \mathrm{CNMR}$ and melting point. Diamin was used to prepare novel polyamides. The low temperature solution polycondensation of diamin with tow aromatic and tow aliphatic diacid chlorides afforded diamin-containing polyamides with inherent viscosities of $0.38-0.47 \mathrm{dl} / \mathrm{g}$ in DMF at $25^{\circ} \mathrm{C}$. The polyamides were generally soluble in a wide range of solvents such as dimethylformamide(DMF), N-Methylpyrolidone(NMP), tetrachloroethane (TCE), dimethylsulfoxide(DMSO) and $\mathrm{H}_{2} \mathrm{SO}_{4}$. Thermal analysis showed that these polyamides were practically crustily and with $\mathrm{T}_{\mathrm{g}}$ under $100{ }^{\circ} \mathrm{C}$.
\end{abstract}

Keywords: polyamides, thermalstability, polycondensation, acenaphthoqinone.

\section{Introduction}

Acenaphthoquinone is a quinone derived from acenaphthene. It is insoluble in water, but soluble in alcohol. It is used as an intermediate for the manufacturing of dyes, pharmaceuticals and pesticides. It is also used in chemical research as a drug and therapeutic agent. Triazole derivatives have been reported as a class of useful heterocyclic compounds, and have found widespread applications in the fields of agrochemicals and pharmaceuticals ${ }^{[1,2]}$. We have synthetized a diamin that produced of reaction of acenaphtochinon with Triazole derivatives and is used for production of thermally stable polyamides. Polyamides are characterized as high temperature resistant materials with a favorable balance of other physical and chemical properties ${ }^{[3]}$. Aromatic polyamides have the poor process ability due to their insolubility in common organic solvents and extremely high glass transition or melt temperature. The synthesis of soluble polyamides without deteriorating their excellent properties $^{[4-10]}$. DSC studies of some polyamides ${ }^{[11,12]}$ were reported in literature. We successfully prepared aromatic polyamides $^{[13]}$, polyimides ${ }^{[14]}$, polyesters, polyquinoxalines, from a number of new functional monomers ${ }^{[15]}$. Thermally stable polymers have received extensive interest due to the increasing demands for high temperature polymers as replacements for ceramics and metals in the automotive, aerospace, and microelectronics industries. Aromatic polyamides are one of the most important classes of high performance polymers, because they possess excellent mechanical properties, thermal stability, chemical resistance, and low flammability. However, they encounter processing difficulties due to limited solubility in organic solvents and high glass transition or melting temperatures. It is a result of chain stiffness and intermolecular hydrogen bonding between amide groups. In this article, we report the synthesis of polyamides by low temperature solution polycondensation of diamin with tow aromatic and tow aliphatic diacid chlorides such as terephthaloyldichloride
(TP), isophthaloyldichloride(IP), adipoylchloride(AP) and sebacoyldichloride (SC) . Physical properties of polymers including characterization, inherent viscosity, solubility, and thermal properties are also reported.

\section{Experimental}

\subsection{Materials and instruments}

Acenaphthoqinone, 4-amino-3-hydrazino-5-mercapto1,2,4-triazole and other reagents and solvents were purchased from Fluka and used without purification. ${ }^{1} \mathrm{HNMR}$ and ${ }^{13} \mathrm{CNMR}$ spectra were recorded on a $500 \mathrm{MHz}$ Bruker Advance DRX instrument using DMSO- $\mathrm{d}_{6}$ as solvent and tetramethyl silane as an internal standard. FTIR spectra were recorded using a Bruker Vector 22 spectrometer on $\mathrm{KBr}$ pellets. The CHN- 600 Leco analyzer was used for elemental analysis. Thermal gravimetric analysis (TGA) and differential scanning calorimetry (DSC) analysis were performed using Perkin-Elmer Pyris and Metler Tolledo $822^{\mathrm{e}}$, respectively. Inherent viscosity $\left(\eta_{\text {inh }}=\operatorname{Ln} \eta_{\text {rel }} / C\right)$ of polymers were determined for solution of $0.5 \mathrm{~g} / \mathrm{dl}$ in NMP at $25^{\circ} \mathrm{C}$ using an ubbelohde viscometer. Total sulfur was measured using Tanaka Model RX-360 SH.

\section{Preparation of Monomers}

\subsection{Acenaphtohydrazinomercaptotriazoldiamine (AHTD)}

The 1,2-dihydro-acenaphtylene-1,2-dione (1.82 g, $10 \mathrm{mmol}$ ) was dissolved in $25 \mathrm{ml}$ of ethanol and $1 \mathrm{ml}$ of conc. $\mathrm{HCl}$ and then added to a suspension of 4-amino-3hydrazino-5-mercapto-1,2,4-triazole (2.92 g, $20 \mathrm{mmol})$ in $25 \mathrm{ml}$ of ethanol and $5 \mathrm{ml}$ water. The mixture was stirred for $10 \mathrm{~h}$ at reflux temperature. The orange solid was filtered off, washed with ethanol and water and dried in a vacuum 
oven at $70{ }^{\circ} \mathrm{C}$. A orange solid product was obtained in a $65 \%$ yield which starts to melt at $260{ }^{\circ} \mathrm{C}$.

The chemical structure of diamine and its procedure is shown in Scheme 1.

\section{Preparation of Polyamides}

\subsection{Polyacenaphtohydrazinomercaptotriazolterephthalate (PA1)}

A typical procedure for the preparation of polyamides is given in Scheme 2. A $100 \mathrm{ml}$ two-necked flask equipped with a dropping funnel and gas inlet tube was charged with a mixture of AHTD $(0.656 \mathrm{~g}, 2 \mathrm{mmol}), 30 \mathrm{ml}$ dimethylformamide
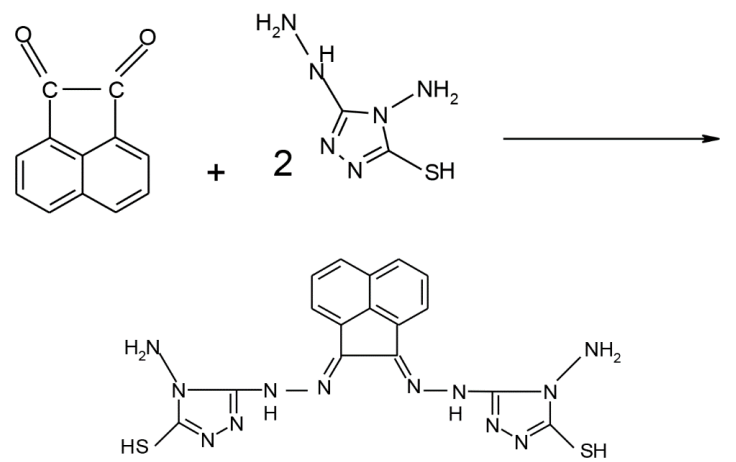

Scheme 1. The procedure for the preparation of Diamine.
(DMF) and triethylamine (0.8 ml). 2 mmol Diacidchloride (DC) (such as terephthaloyl chloride, isophthaloyl chloride, adipoyl chloride and sebacoyl chloride) dissolved in $20 \mathrm{ml}$ DMF was added dropwise to the stirred solution at $0{ }^{\circ} \mathrm{C}$ under $\mathrm{N}_{2}$. The mixture was subsequently stirred at ambient temperature for $5 \mathrm{~h}$ under $\mathrm{N}_{2}$, and then it was poured into cold water. The orange solid product was separated by filtration and washed with $\mathrm{NaHCO}_{3}$ solution. Then the solid product dried in vacuum oven at $70{ }^{\circ} \mathrm{C}$. An orange solid product was obtained in a $86 \%$ yield which starts to melt at $280^{\circ} \mathrm{C}$.

\section{Result and Discussion}

\subsection{IR, ${ }^{1}$ HNMR and Elemental Analysis of diamine(AHTD)}

The monomer, AHTD, was prepared according to the procedures which are given in the Scheme 1. IR, ${ }^{1} \mathrm{HNMR}$ and the results of elemental analysis are given in Table 1.

These regions of the IR spectra in Figure 1 are of particular interest, the $3150-3446 \mathrm{~cm}^{-1}\left(\mathrm{NH}\right.$ and $\mathrm{NH}_{2}$ asymmetric and symmetric stretch), 2980 (C-H aromatic ring) $1638(\mathrm{C}=\mathrm{N})$, $1590(\mathrm{C}=\mathrm{C}), 1585 \mathrm{~cm}^{-1}(\mathrm{NH} 2)$ and $908(\mathrm{C}-\mathrm{S})$ and ${ }^{1} \mathrm{HNMR}$, ${ }^{13} \mathrm{CNMR}$ data in Figure 2 and Figure 3 with ${ }^{1} \mathrm{HNMR}\left(\mathrm{CDCl}_{3}\right)$ : $\delta(\mathrm{ppm}) 12.7-12.9(\mathrm{NH}), 7.78-8.3(\mathrm{CH}$ aromatic $), 5.7(\mathrm{NH} 2)$ and 1.1(SH) and ${ }^{13} \mathrm{CNMR}\left(400, \mathrm{DMSO}, \mathrm{d}_{6}, \mathrm{TMS}\right) \delta \mathrm{ppm}$ : $118.87\left(\mathrm{C}_{\mathrm{Ar}}\right), 125.24\left(\mathrm{C}_{\mathrm{Ar}}\right), 127.22\left(\mathrm{C}_{\mathrm{Ar}}\right), 129.49\left(\mathrm{C}_{\mathrm{Ar}}\right)$, $130.95\left(\mathrm{C}_{\mathrm{Ar}}\right), 136.66\left(\mathrm{C}_{\mathrm{Ar}}\right), 133.27(\mathrm{C}=\mathrm{N})$ and $179.23(\mathrm{C}-\mathrm{S})$

The polyamides were synthesized by direct polycondensation of aromatic and aliphatic diacidchlorides (Scheme 2) with<smiles>[R]C(=O)Cl</smiles><smiles>[R]C(=O)Nn1c(S)nnc1NN=C1C(=NNc2nnc(S)n2NC(C)(C)CC)c2cccc3cccc1c23</smiles>

R :<smiles>c1ccccc1</smiles><smiles>c1ccccc1</smiles>

PA2
$-\left(\mathrm{CH}_{2}\right)_{4}-$

PA3
$-\left(\mathrm{CH}_{2}\right)_{8}-$

Scheme 2. The typical procedure for the preparation of polyamides. 
AHTD using triethylamine as catalyst. The reactions were carried out in DMF solution of the diacidchloride and AHTD in a nitrogen atmosphere and at room temperature. The polymerizations proceeded in homogeneous solution and the yields of the polyamides were quantitative. The elemental analysis values of all the polyamides, Table 1, were generally in good agreement with the calculated values of proposed structures. As representative example,

Table 1. Spectra data, elemental analysis results and the yield of polyamides.

\begin{tabular}{|c|c|c|c|c|c|c|c|c|}
\hline \multirow[t]{3}{*}{ Substrate } & \multirow[t]{3}{*}{ IR (KBr, cm_1) } & \multirow{3}{*}{$\begin{array}{c}\text { NMR } \\
\text { (DMSO-d6, } \delta, ~ p p m)\end{array}$} & \multicolumn{6}{|c|}{ Elemental analysis } \\
\hline & & & \multicolumn{3}{|c|}{ Calc. } & \multicolumn{3}{|c|}{ Found } \\
\hline & & & $\mathrm{C}$ & $\mathbf{H}$ & $\mathbf{N}$ & $\mathrm{C}$ & $\mathbf{H}$ & $\mathbf{N}$ \\
\hline AHTD & $\begin{array}{l}3150-3446 \mathrm{~cm}^{-1}(\mathrm{NH} \\
\text { and } \mathrm{NH}_{2} \text { asymmetric } \\
\text { and symmetric } \\
\text { stretch }), 2980(\mathrm{C}-\mathrm{H} \\
\text { aromatic ring), } \\
1638(\mathrm{C}=\mathrm{N}), 1590 \\
(\mathrm{C}=\mathrm{C}), 908(\mathrm{C}-\mathrm{S})\end{array}$ & $\begin{array}{c}\text { 12.7-12.9(NH), 7.78, } \\
\text { 8.3(CH,Aromatic), } \\
\text { 5.7(NH2), 1.1(SH) }\end{array}$ & 43.84 & 3.19 & 38.35 & 44.12 & 3.25 & 37.92 \\
\hline PA1 & $\begin{array}{l}3430(\mathrm{~N}-\mathrm{H}), 3100 \\
(\mathrm{C}-\mathrm{H} \text { aromatic }), 1790 \\
(\mathrm{C}=\mathrm{O}), 1631(\mathrm{C}=\mathrm{N}), \\
1527(\mathrm{C}=\mathrm{C} \text { aromatic }), \\
910(\mathrm{C}-\mathrm{S})\end{array}$ & $\begin{array}{c}12.7(\mathrm{NH}), 7.8-8.8 \\
(\mathrm{CH} \text { Aromatic }) \\
1.1(\mathrm{SH})\end{array}$ & 50.70 & 2.82 & 29.57 & 51.02 & 2.98 & 28.98 \\
\hline PA2 & $\begin{array}{l}3300(\mathrm{~N}-\mathrm{H}), 3117 \\
(\mathrm{~N}-\mathrm{H}), 2965(\mathrm{C}-\mathrm{H} \\
\text { aromatic }), 1636 \\
(\mathrm{C}=\mathrm{O}), 1560(\mathrm{C}=\mathrm{N}), \\
1508(\mathrm{C}=\mathrm{C} \text { aromatic }), \\
910(\mathrm{C}-\mathrm{S})\end{array}$ & $\begin{array}{c}12.7(\mathrm{NH}), 7.8-8.8 \\
(\mathrm{CH} \text { Aromatic }) \\
1.1(\mathrm{SH})\end{array}$ & 50.70 & 2.82 & 29.57 & 51.32 & 3.02 & 28.83 \\
\hline PA3 & $\begin{array}{l}3210(\mathrm{~N}-\mathrm{H}), 3000 \\
(\mathrm{C}-\mathrm{H} \text { aromatic }), \\
2800(\mathrm{C}-\mathrm{H} \text { aliphatic }) \\
1638(\mathrm{C}=\mathrm{O}), 1590 \\
(\mathrm{C}=\mathrm{N}), 1476(\mathrm{C}=\mathrm{C} \\
\text { aromatic }), 910(\mathrm{C}-\mathrm{S})\end{array}$ & $\begin{array}{c}12.8(\mathrm{NH}), 7.1-8.4 \\
(\mathrm{CH} \text { Aromatic }) \\
1.9-2.1(\mathrm{CH} 2) \\
1.1(\mathrm{SH})\end{array}$ & 48.17 & 3.65 & 30.65 & 47.92 & 3.56 & 31.03 \\
\hline PA4 & $\begin{array}{l}3430(\mathrm{~N}-\mathrm{H}), 2900 \\
(\mathrm{C}-\mathrm{H} \text { aliphatic }) 1636 \\
(\mathrm{C}=\mathrm{O}), 1570(\mathrm{C}=\mathrm{N}), \\
1505(\mathrm{C}=\mathrm{C} \text { aromatic }), \\
910(\mathrm{C}-\mathrm{S})\end{array}$ & $\begin{array}{c}12.8(\mathrm{NH}), 7.1-8.4 \\
(\mathrm{CH} \text { Aromatic }) \\
1.9-2.8(\mathrm{CH} 2) \\
1.1(\mathrm{SH})\end{array}$ & 51.65 & 4.64 & 27.81 & 51.89 & 4.35 & 28.12 \\
\hline
\end{tabular}

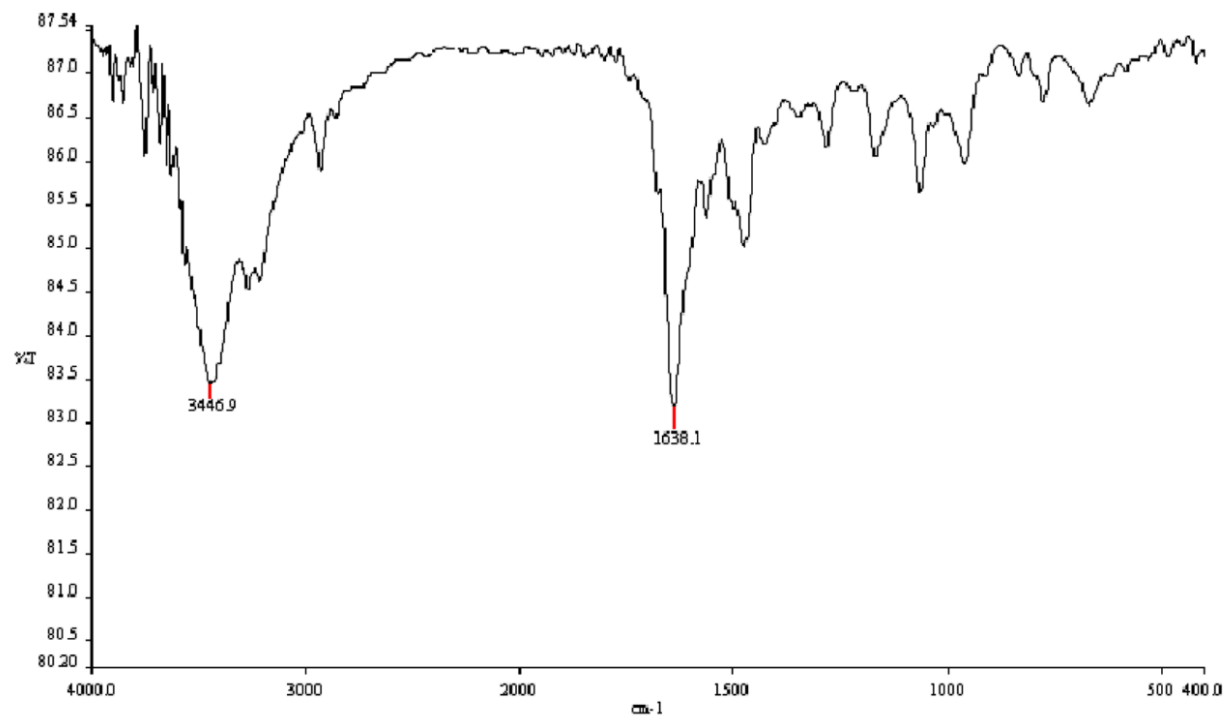

Figure 1. IR spectra of diamine. 


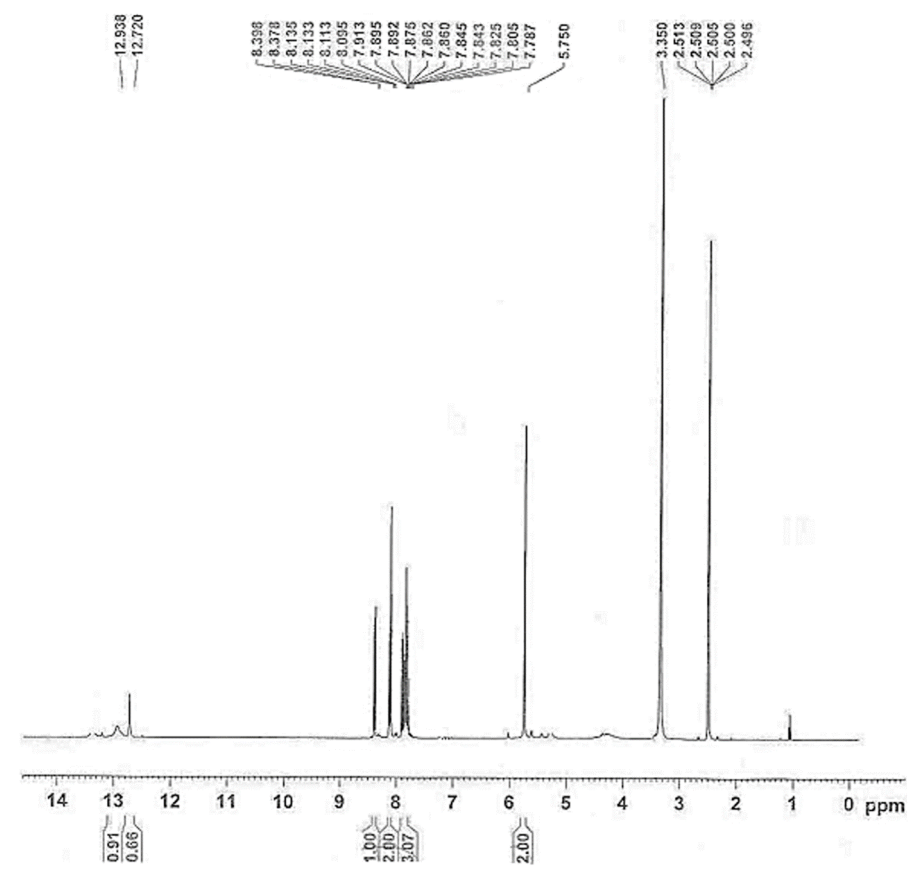

Figure 2. ${ }^{1} \mathrm{HNMR}$ spectra of diamine.

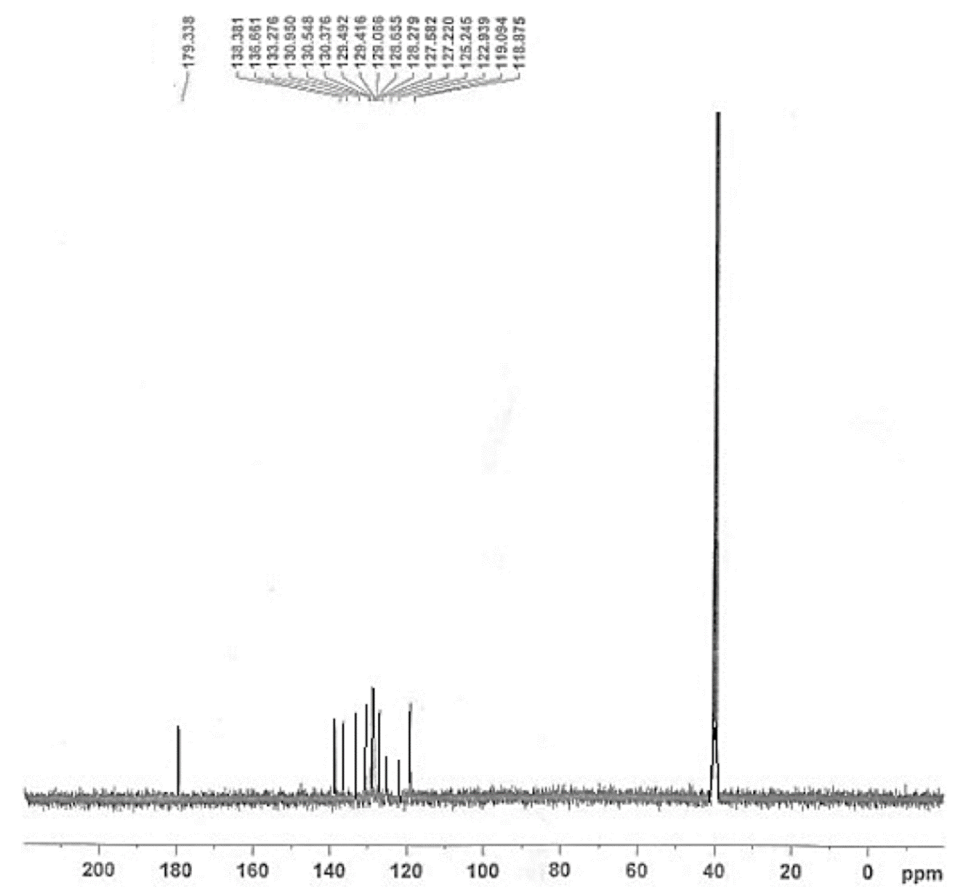

Figure 3. ${ }^{13} \mathrm{CNMR}$ spectra of diamine. 
the complete elemental analysis of PA1 was as follows: C, $50.70 \%$ (51.02\% calculated); H, 2.82\% (3.21\%); N, 29.57\% (28.58\%). The polyamides were also characterized by IR and NMR spectrometers. The presence of amide bands at ca. $3430 \mathrm{~cm}^{-1}$ (N-H stretching), $1790 \mathrm{~cm}^{-1}$ ( $\mathrm{C}=\mathrm{O}$ stretching), $1631 \mathrm{~cm}^{-1}$ (N-H bending and C-N stretching) and $910 \mathrm{~cm}^{-1}$ (C-S), in the IR spectra in Figure 4 for PA1 and amidic proton at ca. $12.5 \mathrm{ppm}$ in the NMR spectra of PA1 in Figure 5 confirmed the amidic structure of polymers.

The limiting viscosity number [ $\eta]$ of polyamides was determined for extracted and dried polymers in DMF, depending on the solubility of the polyamide. For the same or similar type of linear polymers the [ $\eta]$ value is proportional to the molecular mass. The inherent viscosities of polyamides (PA1-PA4), obtained in DMF were in the

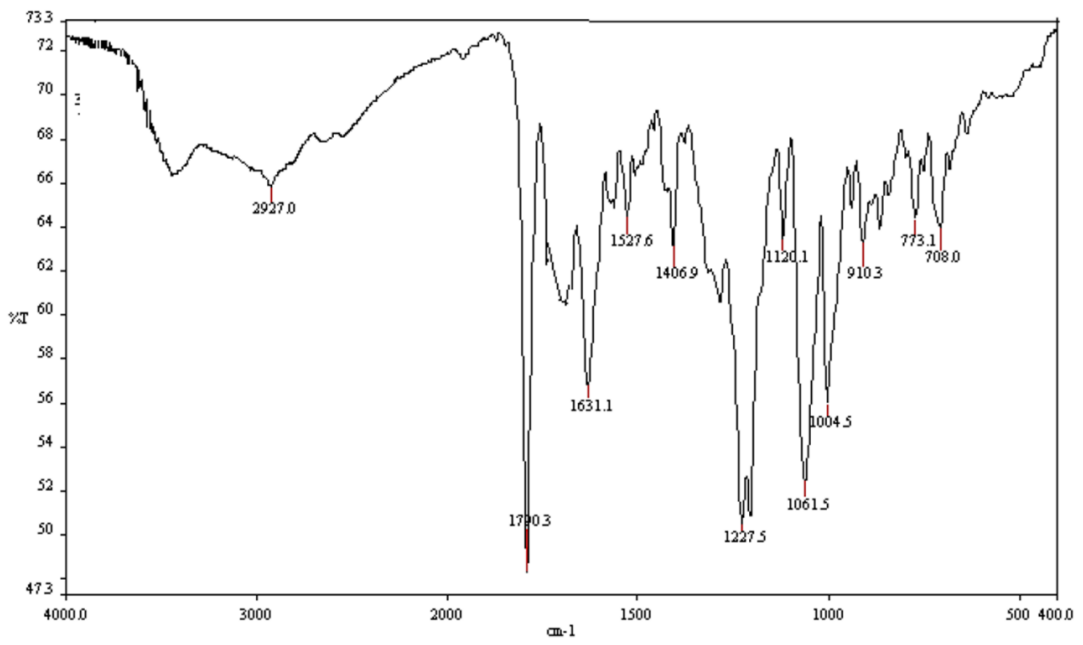

Figure 4. FTIR spectra of PA1.
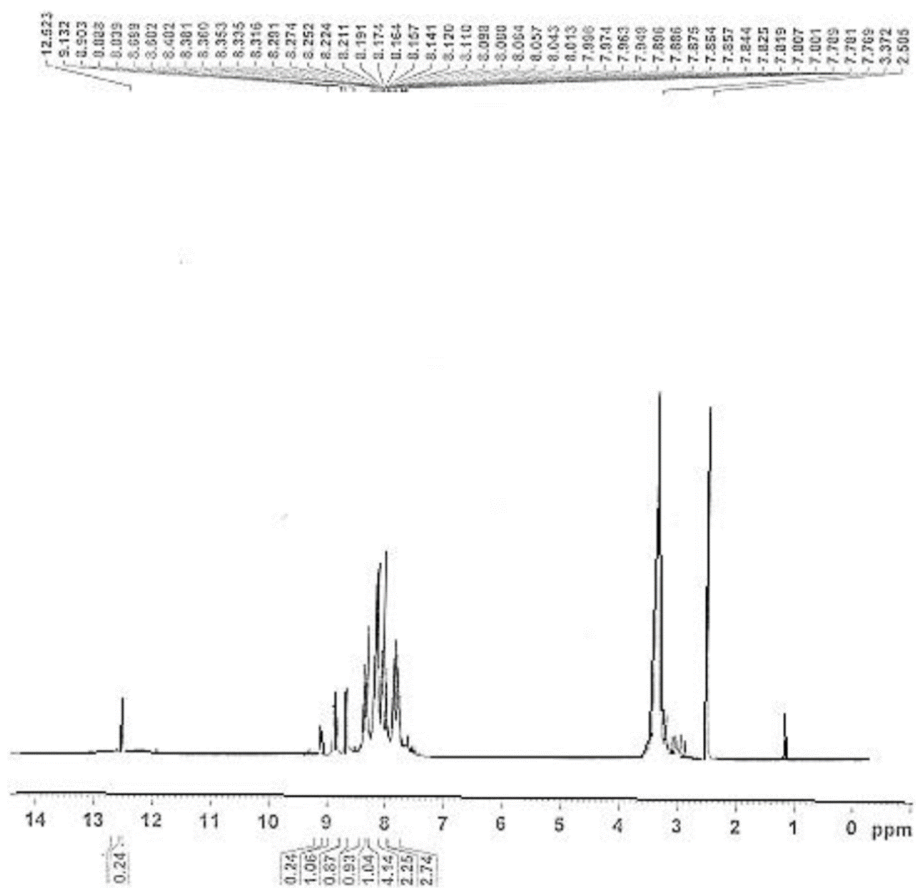

Figure 5. ${ }^{1} \mathrm{HNMR}$ spectra of PA1. 
range of $0.38-0.47 \mathrm{dl} / \mathrm{g}$ that revealed reasonable molecular weights. The limiting viscosity number [ $\eta]$ of aromatic polyamides is less than aliphatic polyamides.

One of the major objectives of this study was producing modified polyamides with improved solubility. The solubility of these polyamides was determined for the powdery samples in excess solvents and the results are listed in Table 2.

All the polyamides were readily soluble in common polar aprotic solvents without need for heating. Also, by heating they were soluble in a less efficient solvent such as THF. The good solubility behavior of most prepared polyamides can be explained through the enhancement of solubility induced by the side biphenyl groups of the diamine moiety. The thermal behavior of polyamides was studied by DSC and TGA.. Thermal properties of the prepared polyamides were evaluated by means of DSC and TGA. Representative DSC and TGA thermograms are shown in Figures 6, 7, 8 and 9 for two aromatic and aliphatic polyamides(PA2,PA3).

The DSC curves of Polyamides(PA2,PA3) were shown the glass transition temperature of these polymers at $65^{\circ} \mathrm{C}$ and $55^{\circ} \mathrm{C}$ and cristallinity temperature of both polymers at $251{ }^{\circ} \mathrm{C}$ and the melt temperature of polymers at $330{ }^{\circ} \mathrm{C}$ and $310^{\circ} \mathrm{C}$ respectively. The DSC curves showed that the aliphatic polyamides have lower glass transition temperature such as aromatic polyamides and they have certainly melt temperature less than aromatic polyamides.

The thermal stability of polyamides was also evaluated by TGA. The temperatures of the $10 \%, 25 \%$ and $50 \%$ weight loss and the remained polyamides at $600{ }^{\circ} \mathrm{C}$ in nitrogen atmosphere were given in Table 3 .

Table 2. Solubility of polyamides.

\begin{tabular}{|c|c|c|c|c|c|c|c|c|c|c|c|c|}
\hline Polym. code & NMP & DMF & DMSO & TCE & THF & $\mathrm{H}_{2} \mathrm{SO}_{4}$ & HMPA & DMAC & Aceton & Ethanol & Methanol & $\mathrm{CHCl}_{3}$ \\
\hline AHTD & + & + & + & + & + & + & + & + & + & + & + & \pm \\
\hline PA1 & + & + & + & \pm & + & + & + & + & - & \pm & - & \pm \\
\hline PA2 & + & + & + & \pm & + & + & + & + & - & \pm & - & \pm \\
\hline PA3 & + & + & + & \pm & + & + & \pm & + & - & \pm & - & \pm \\
\hline PA4 & + & + & + & \pm & + & + & \pm & + & - & \pm & - & \pm \\
\hline
\end{tabular}

Soluble $(+)$, partially soluble $( \pm)$, insoluble (-) Solubility tested with $0.5 \mathrm{~g}$ of polymer in $100 \mathrm{ml}$ of solvent. NMP=N-methylpyrolidone, $\mathrm{DMF}=$ dimethylformamide, DMSO=dimetylsolfoxide, TCE=tetrachloroethane, Py=pyridine, THF=tetrahydrofurane, $\mathrm{HMPA}=$ hexamethylenphosphoramide, $\mathrm{DMAC}=$ dimethylacetamide.

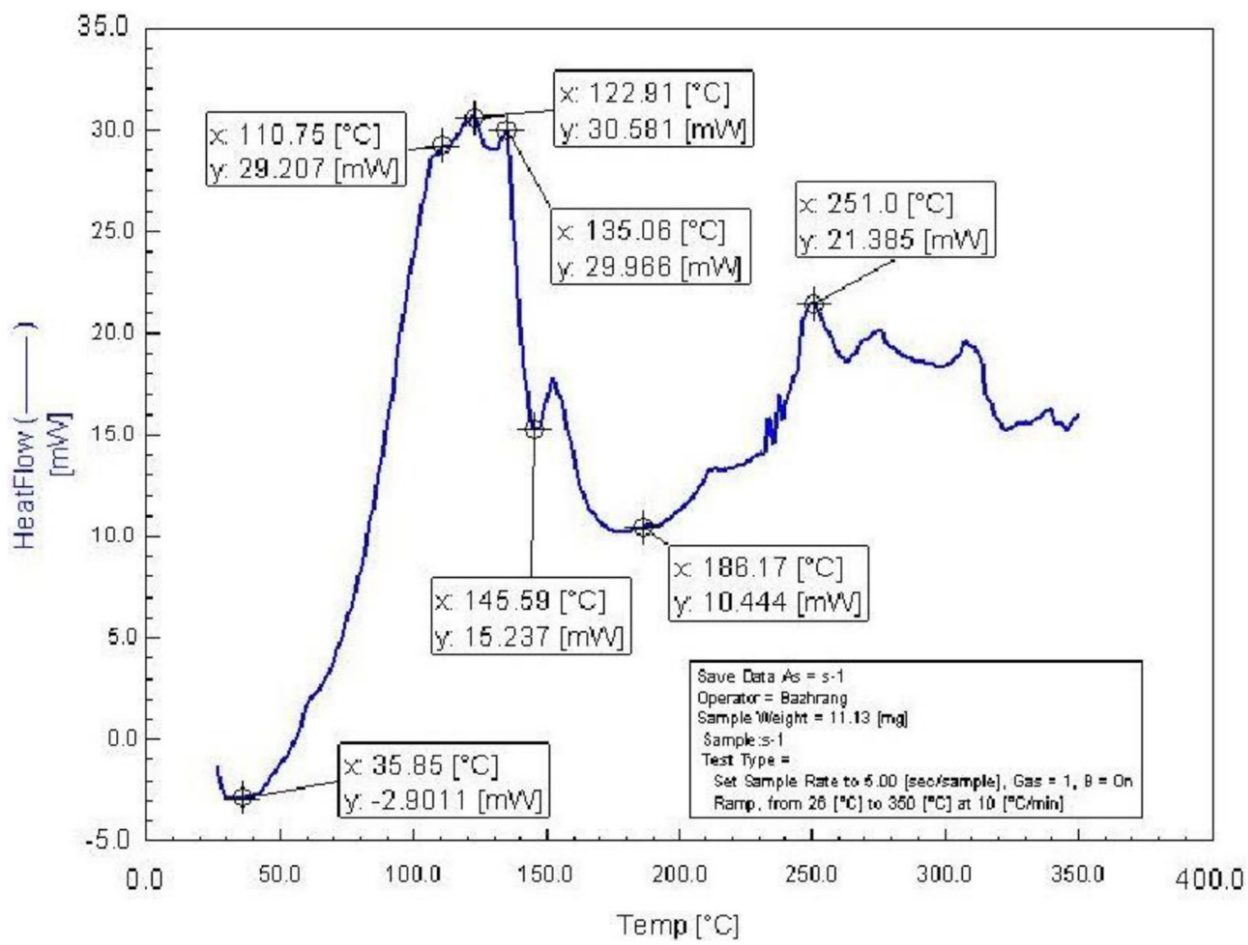

Figure 6 . DSC of PA2. 


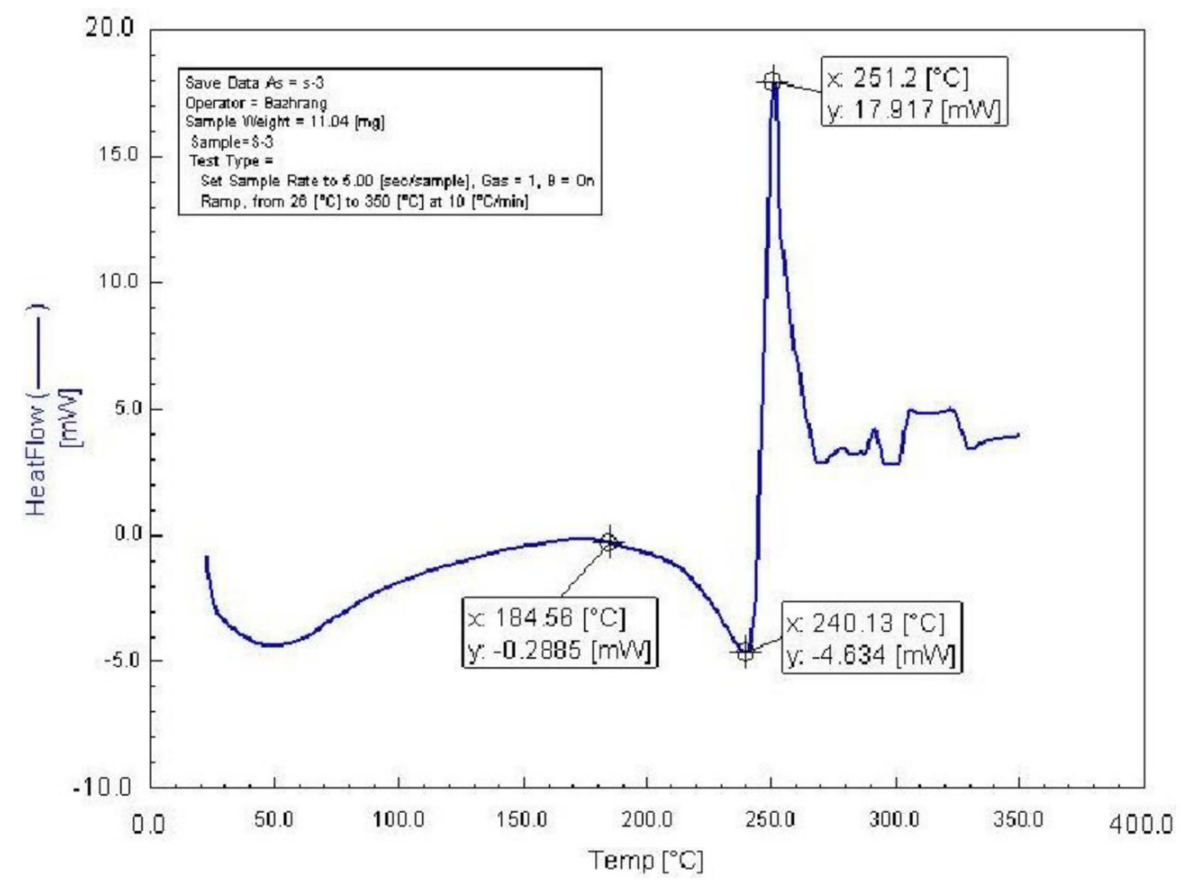

Figure 7 . DSC of PA3.

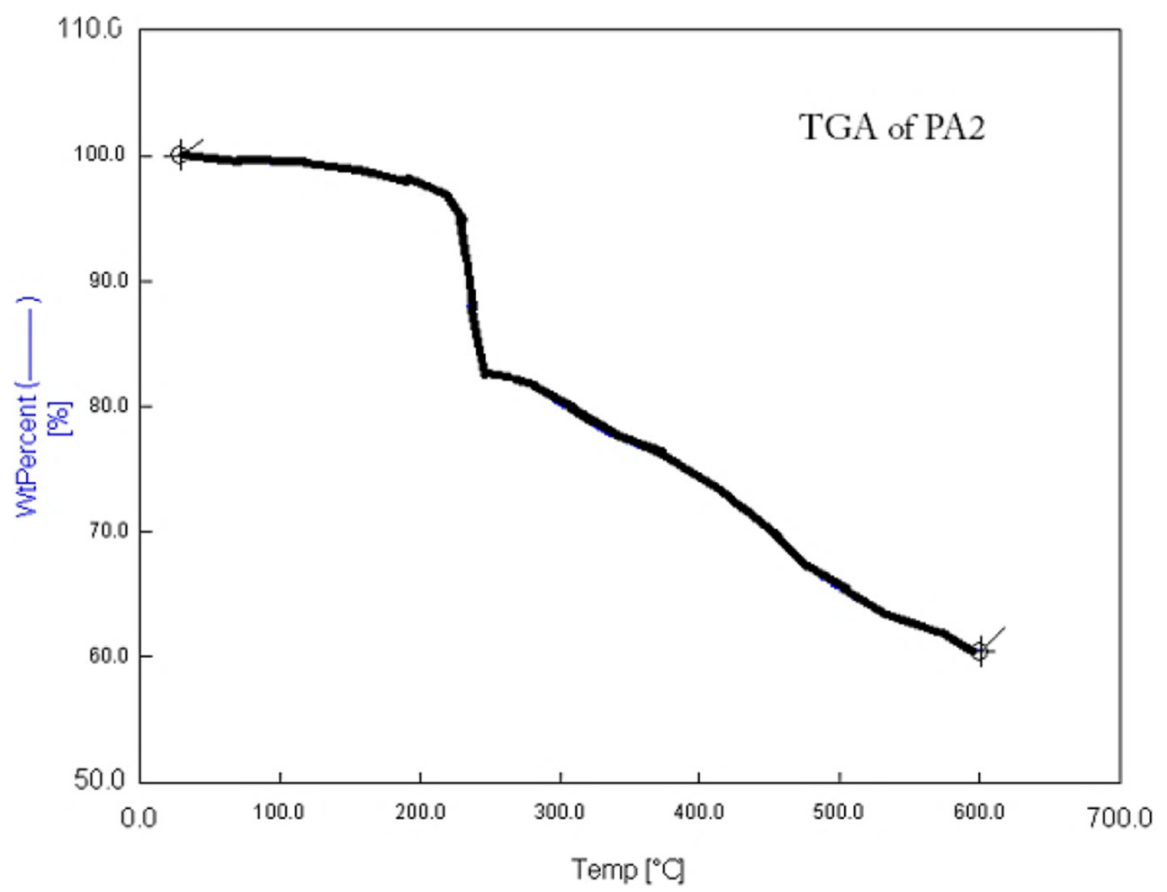

Figure 8. TGA of PA2. 


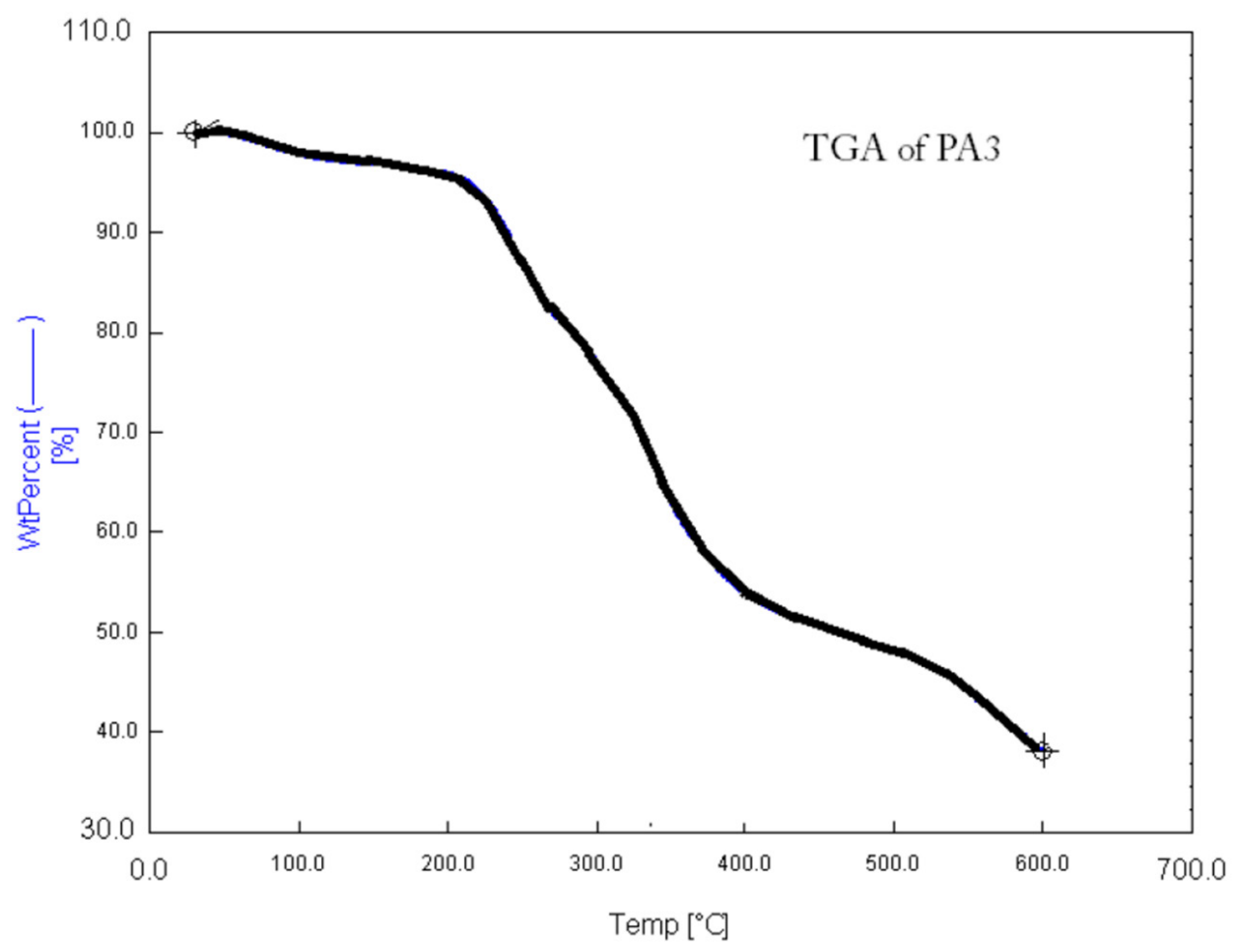

Figure 9 . TGA of PA3.

Table 3. Thermal analysis, viscosity and yield of the polyamides.

\begin{tabular}{ccccccccc}
\hline Compound code & $\mathbf{T}_{\mathbf{g}}$ & $\mathbf{T}_{\mathbf{c}}$ & $\mathbf{T}_{\mathbf{m}}$ & $\mathbf{T}_{\mathbf{1 0}}\left({ }^{\circ} \mathbf{C}\right)^{\mathbf{a}}$ & $\mathbf{T}_{\mathbf{2 5}}\left({ }^{\circ} \mathbf{C}\right)^{\mathbf{b}}$ & $\mathbf{T}_{\mathbf{5 0}}\left({ }^{\circ} \mathbf{C}\right)^{\mathbf{c}}$ & $\mathbf{\%}_{\mathbf{0}} \mathbf{C h} . \mathbf{Y} \cdot{ }^{\mathbf{d}}$ & $\begin{array}{c}\boldsymbol{\eta}_{\text {inh }} \\
(\mathbf{d l l} / \mathbf{g})^{\mathbf{e}}\end{array}$ \\
\hline AHTD & - & - & 260 & - & - & - & - & 0.04 \\
PA1 & 90 & 251 & 320 & 230 & 320 & 420 & 42 & 0.38 \\
PA2 & 65 & 251 & 330 & 230 & 400 & - & 60 & 0.42 \\
PA3 & 55 & 251 & 310 & 220 & 310 & 450 & 38 & 0.45 \\
PA4 & 50 & 240 & 310 & 180 & 290 & 340 & 16 & 0.47 \\
\hline
\end{tabular}

$\mathrm{T}_{\mathrm{g}}$ Glasstransition Temperature. $\mathrm{T}_{\mathrm{c}}$ cristallinity Temperature $\mathrm{T}_{\mathrm{m}}$ Melting temperature. ${ }^{\mathrm{a}} 10 \%$ weight loss. ${ }^{\mathrm{b}} 25 \%$ weight loss. ${ }^{\mathrm{c}} 50 \%$ weight loss. ${ }^{\mathrm{d}} \mathrm{g}$ har yield percent at $600^{\circ} \mathrm{C}$, obtained from TGA. ${ }^{\mathrm{e}}$ Measured in DMF at $25^{\circ} \mathrm{C}(\mathrm{c}=0.5 \mathrm{~g} / \mathrm{dl})$.

All the polymers were stable up to $200{ }^{\circ} \mathrm{C}$ in nitrogen and show almost the same stability. We found that these polyamides did not show obvious weight losses until the temperature reached $200^{\circ} \mathrm{C}$ in nitrogen, implying that no thermal decomposition occurred. However, as the temperature over $200^{\circ} \mathrm{C}$, the polymers showed a rapid thermal decomposition. The $10 \%$ weight loss of all polymers was in temperature range of $180-230{ }^{\circ} \mathrm{C}$. The $25 \%$ weight loss of all polymers was in temperature range of $290-320^{\circ} \mathrm{C}$. The $50 \%$ weight loss of all polymers was in temperature range of $340-450{ }^{\circ} \mathrm{C}$. The polyamides (PA1,PA2) remained $42-60 \%$ of the original weight at $600{ }^{\circ} \mathrm{C}$ in nitrogen and the polyamides (PA3,PA4) remained over $16-38 \%$ of the original weight at $600{ }^{\circ} \mathrm{C}$ in nitrogen. Two of the polyamides(aliphatic) exhibited a more weight loss at the same temperature and they have a short char yield against aromatic polyamides.

\section{Conclusion}

A series of polyamides were prepared from the reaction of two aromatic and two aliphatic diacid chlorides with a diamine AHTD. The molar ratio of diacid chloride to the AHTD was 2:2 and the reaction was carried out at ambient temperature for $5 \mathrm{~h}$ under $\mathrm{N}_{2}$ atmosphere. The polyamides were fully characterized and their thermal properties were studied. Two of the polyamides(aliphatic) exhibited a more weight loss at the same temperature and they have a short char yield against aromatic polyamides. The introduction of aromatic side groups in structure of the diamine resulted 
in crystalline polyamides that the degree of crystallinity has a big influence on hardness, density, transparency and diffusion. The polyamides have very good solubility in aprotic solvents such as DMF and generally, the solubility of aromatic polyamides were better in selected solvents. Aliphatic polyester hopes of higher inherent viscosity and thus had a higher molecular weight. The glass temperature of the aliphatic polyamides was lower than aromatic polyamides but unlike crystalline temperature and melting temperature are close together and the differences were not significant.

\section{References}

1. Maxwell, J. R., Wasdahl, D. A., Wolfson, A. C., \& Stenberg, V. I. (1984). Synthesis of 5-aryl-2H-tetrazoles, 5-aryl-2Htetrazole-2-acetic acids, and [(4-phenyl-5-aryl-4H-1,2,4-triazol3 -yl)thio]acetic acids as possible superoxide scavengers and antiinflammatory agents. Journal of Medicinal Chemistry, 27(12), 1565-1570. http://dx.doi.org/10.1021/jm00378a007. PMid:6094808.

2. Vicentini, C. B., Manfrini, M., Veronese, A. C., \& Guarneri, M. (1998). Synthesis of 4-(pyrazol-5-yl)-1,2,4-triazole-3-thiones. Journal of Heterocyclic Chemistry, 35(1), 29-32. http://dx.doi. org/10.1002/jhet.5570350106.

3. Couderchet, M., Schmalfuß, J., \& Böger, P. (1998). A specific and sensitive assay to quantify the herbicidal activity of chloroacetamides. Pesticide Science, 52(4), 381-387. http:// dx.doi.org/10.1002/(SICI)1096-9063(199804)52:4<381::AIDPS735>3.0.CO;2-8.

4. Cassidy, P. E. (1980). Thermally stable polymers. New York: Marcel Dekker.

5. Imai, Y., Maldar, N. N., \& Kakimoto, M. (1984). Synthesis and characterization of soluble aromatic polyazomethines from 2,5-bis(4-aminophenyl)-3,4 diphenylthiophene and aromatic dialdehydes. Journal of Polymer Science: Polymer Chemistry Edition, 22(12), 3771-3778. http://dx.doi.org/10.1002/ pol.1984.170221214.

6. Liaw, D.-J., Uexama, N., \& Havada, A. (2004). In N. Ueyama \& A. Harada (Eds.), Macromolecules nanostructured materials (chap. 2.2, pp. 80). Berlin: Springer.

7. Liaw, D.-J. (2005). Optically high transparency and light color of organosoluble polyamides containing trifluoromethyl and kink diphenylmethylene linkage. Journal of Polymer Science.
Part A, Polymer Chemistry, 43(19), 4559-4569. http://dx.doi. org/10.1002/pola.20782.

8. Liaw, D.-J., Huang, C. C., \& Chen, W. H. (2006). Color lightness and highly organosoluble fluorinated polyamides, polyimides and poly(amide-imide)s based on noncoplanar 2,2'-dimethyl-4,4'-biphenylene units. Polymer, 47(7), 23372348. http://dx.doi.org/10.1016/j.polymer.2006.01.028.

9. Wu, S.-C., \& Shu, C. F. (2003). Synthesis and properties of soluble aromatic polyamides derived from 2,2'-bis(4carboxyphenoxy)-9,9'-spirobifluorene. Journal of Polymer Science. Part A, Polymer Chemistry, 41(8), 1160-1166. http:// dx.doi.org/10.1002/pola.10657.

10. Yang, C.-P., Hsiao, S.-H., \& Lin, J.-H. (1992). New poly(amideimide)s syntheses. II. Soluble poly(amide-imide)s derived from 2,5-bis(4-aminophenyl)-3,4-diphenylthiophene and various $\mathrm{N}$-( $\omega$-carboxyalkyl)-trimellitimides, $\mathrm{N}$-(carboxyphenyl) trimellitimides, or N,N"-bis( $\omega$-carboxyalkyl)pyromellitimides. Journal of Polymer Science. Part A, Polymer Chemistry, 30(9), 1865-1872. http://dx.doi.org/10.1002/pola.1992.080300909.

11. Siracusa, G., Pollicino, A., \& Borrello, G. M. (1997). The preparation by a solid-solid interaction route of aromatic polyamide materials containing sulphone, ether and ketone linkages. Journal of Thermal Analysis and Calorimetry, 50(4), 633-646. http://dx.doi.org/10.1007/BF01979035.

12. Fujimura, T., Sarugaku, N., Tsuchiya, M., Ishimaru, K., \& Kojima, T. (2001). Thermogravimetric Analysis of Aromatic Polyamides with Various Benzimidazolyl Contents. Journal of Thermal Analysis and Calorimetry, 64(2), 425-431. http:// dx.doi.org/10.1023/A:1011516804961.

13. Ghaemy, M., Mighani, H., \& Alizadeh, R. (2011). Synthesis and characterization of Schiff-base-containing polyamides. Chinese Journal of Polymer Science, 29(2), 148-155. http:// dx.doi.org/10.1007/s10118-010-1004-8.

14. Ghaemy, M., \& Mighani, H. (2010). Synthesis and characterization of Schiff-base-containing polyimides. Journal of Applied Polymer Science, 118(5), 2496-2501. http://dx.doi.org/10.1002/ app. 31178 .

15. Ghaemy, M., Mighani, H., \& Ziaei, P. (2009). Synthesis and characterization of novel organosoluble polyesters based on a DIOL with azaquinoxaline ring. Journal of Applied Polymer Science, 114(6), 3458-3463. http://dx.doi.org/10.1002/app.30726.

Received: Aug. 31, 2014

Revised: Jan. 18, 2015

Accepted: Feb. 26, 2015 